\title{
LAND SUBSIDENCE ANALYSIS CAUSED BY AQUIFER OVEREXPLOITATION USING GEP TOOLS: A-DINSAR ON THE CLOUD
}

\section{MEDICIÓN DE SUBSIDENCIA DEL TERRENO CAUSADA POR SOBREEXPLOTACIÓN DE ACUÍFEROS MEDIANTE HERRAMIENTAS GEP: A-DINSAR EN LA NUBE}

\author{
Guadalupe Brua, ${ }^{\star}$, Pablo Ezquerro ${ }^{a}$, Carolina Guardiola-Alberta, Marta Béjar-Pizarro ${ }^{a}$, Gerardo \\ Herrera ${ }^{a}$, Roberto Tomás ${ }^{b}$, María Inés Navarro-Hernández ${ }^{b}$, Juan M. López-Sanchez ${ }^{c}$, Ali Hakan \\ Ören ${ }^{d}$, Barış Çaylak ${ }^{d}$, Alper Elçie, Khaldoun Shatanawif, Alsharifa Hind Mohammadf, Husam A. Abu \\ Hajar ${ }^{f}$, Roberta Bonìg, Claudia Meisinag \\ a Instituto Geológico y Minero de España (IGME, CSIC). Calle de Ríos Rosas 23, 28003 Madrid, Spain. g.bru@igme.es; \\ p.ezquerro@igme.es; c.guardiola@igme.es; m.bejar@igme.es; g.herrera@igme.es \\ b Departamento de Ingeniería Civil, Universidad de Alicante, Carr. de San Vicente del Raspeig s/n, 03690 San Vicente del Raspeig, \\ Spain. roberto.tomas@ua.es; mainnahe@ua.es \\ ${ }^{c}$ Instituto Universitario de Investigación Informática, Universidad de Alicante, Carr. de San Vicente del Raspeig s/n, 03690 San Vicente \\ del Raspeig, Spain. juanma.lopez@ua.es \\ d Department of Civil Engineering, Dokuz Eylul University, Alsancak, No: 144 35210, Cumhuriyet Blv, 35220 Konak, Turkey. \\ ali.oren@deu.edu.tr; bariscaylak91@gmail.com \\ e Department of Environmental Engineering, Dokuz Eylul University, Alsancak, No: 144 35210, Cumhuriyet Blv, 35220 Konak, Turkey. \\ alper.elci@deu.edu.tr \\ f Water, Energy and Environment Center, University of Jordan, Queen Rania St, Amman, Jordan. kshatanawi@ju.edu.jo; \\ s.jasem@ju.edu.jo; h.abuhajar@ju.edu.jo \\ ${ }^{9}$ Dipartimento di Scienze della Terra e dell'Ambiente, Universidad de Pavia, Corso Str. Nuova, 65, 27100 Pavia, Italy. \\ claudia.meisina@unipv.it; roberta.boni01@universitadipavia.it
}

\begin{abstract}
:
Groundwater is a vitally important resource for humans. One of the main problems derived from the overexploitation of aquifers is land subsidence, which in turn carries other associated natural risks. Advanced Differential satellite radar interferometry (A-DInSAR) techniques provide valuable information on the surface displacements of the ground, which serve to characterize both the deformational behaviour of the aquifer and its properties. RESERVOIR is a research project belonging to the European PRIMA programme, whose main objective is to design sustainable groundwater management models through the study of four areas of the Mediterranean subjected to water stress. One of the main tasks of the project is the integration of the terrain deformation data obtained with satellite remote sensing techniques in the hydrogeological and geomechanical models of the aquifers. In the present work, a first evaluation of the deformation of the ground in each study area is carried out using the tools contained in the Geohazards Exploitation Platform (GEP). This is a service financed by the European Space Agency (ESA) that allows processing directly on its server, without need to store data or applications locally.
\end{abstract}

Key words: A-DInSAR, GEP, Sentinel-1, aquifer overexploitation, land subsidence

\section{Resumen:}

Las aguas subterráneas son un recurso de vital importancia para el ser humano. Una de las principales problemáticas derivadas de la sobreexplotación de acuíferos es la subsidencia del terreno, que a su vez lleva asociados otros riesgos naturales. Las técnicas avanzadas de interferometría radar diferencial de satélite (A-DInSAR) aportan información muy valiosa sobre los desplazamientos superficiales del terreno, que sirven para caracterizar tanto el comportamiento geomecánico del acuífero como sus propiedades. RESERVOIR es un proyecto de investigación perteneciente al programa europeo PRIMA, cuyo principal objetivo es diseñar modelos sostenibles de gestión de aguas subterráneas mediante el estudio de cuatro zonas del Mediterráneo sometidas a estrés hídrico. Una de las principales tareas del proyecto es la integración de los datos de deformación del terreno obtenidos con técnicas de teledetección por satélite en los modelos hidrogeológicos y geomecánicos de los acuíferos. En el presente trabajo se realiza una primera evaluación de la deformación del terreno en cada zona de estudio utilizando las herramientas contenidas en la Geohazards Exploitation Platform (GEP). Este servicio financiado por la Agencia Espacial Europea (ESA) permite realizar procesados directamente en su servidor, sin necesidad de almacenar datos ni aplicaciones en local.

Palabras clave: A-DInSAR, GEP, Sentinel-1, sobreexplotación de acuíferos, subsidencia

*Corresponding Author: Guadalupe Bru, g.bru@igme.es 


\section{Introduction}

Groundwater is a critical resource that provides fresh drinking water to at least $50 \%$ of the global population and accounts for $43 \%$ of all of the water used for irrigation (Siebert et al. 2010; UNESCO 2012). Groundwater withdrawal in overexploited aquifers can induce soil consolidation and associated land subsidence, which at the same time ensues other impacts, such as permanent reduction of storage capacity in aquifer systems, increase of flooding risk (specially in coastal areas), earth fissures and damage to human infrastructures.

A well-established tool for measuring land subsidence that uses Synthetic Aperture Radar (SAR) satellite acquisitions is the Advanced Differential Interferometry SAR (A-DInSAR) technique (Galloway and Hoffmann 2007; Galloway et al. 1998; Tomás et al. 2014). With the launch of the Sentinel-1 (S-1) mission from the European Space Agency (ESA) in 2014, that provides freely accessible data globally with a revisit time of 6 days, the SAR archive has become huge and is constantly increasing. To handle and be able to process S-1 Big Data by scientists that are non-expert in A-DInSAR, the Geohazards Exploitation Platform (GEP) on-demand web tool was launched in 2015 funded by ESA. The strategy is to co-locate both A-DInSAR algorithms (Thematic Applications) and computational resources close to the SAR data archives, as well as to provide the capability to easily generate A-DInSAR results in a friendly interface. The developed on-demand Thematic Applications permits to set up an efficient on-line service to produce surface deformation mean velocity maps and time series in an unsupervised manner (De Luca et al. 2015). The concept "unsupervised" stands for the fact that the processing chains run automatically in the server without user interaction. The efficiency and robustness of the chain guarantee the achieved result accuracy.

In this work we present a preliminary land subsidence detection by means of line-of-sight LOS velocity maps obtained in the GEP platform, in the four pilot sites of the RESERVOIR PRIMA project. We discuss the performance of the two different Thematic Applications that were used (P-SBAS and FASTVEL algorithms) and address their suitability to study surface displacements related to aquifer system deformation.

\section{Studied sites}

The RESERVOIR project funded by the PRIMA programme supported by the European Union, aims to provide new products and services for a sustainable groundwater management model to be developed and tested in four water-stressed Mediterranean pilot sites, and which then would be applicable in other regions via an interdisciplinary approach. The pilot sites are located in Italy (coastal aquifer of Comacchio), Spain (Alto Guadalentín Basin), Turkey (Gediz River Basin) and Jordan (Azraq Wetland Reserve) (Fig. 1). The water usages of these aquifers are irrigation, drinking water and/or power generation. Each site is prone to different issues such as land subsidence, salt water intrusion, water pollution, over-exploitation and insufficient recharge.

The aquifer of Comacchio is in the coastal floodplain of the Po River in north-eastern Italy. The geological setting is formed by a $700-800 \mathrm{~m}$ thick sedimentary sequence of continental and marine deposits accumulated during the Pliocene-Pleistocene (Castellarin et al. 1985; Pieri and Groppi 1981) which led to a complex hydrogeological aquifer system. The primary land use of the area is intensive horticultural crops. During the summer season water demand increases significantly as a result of tourism along the coastline. This pilot site is affected by various threats: saltwater intrusion in the phreatic aquifer and seawater encroachment inland along the rivers (Giambastiani et al. 2007); natural (Carbognin and Tosi 1995; Carminati et al. 2005) and anthropogenic land subsidence (Teatini et al. 2006); land reclamation drainage systems; soil salinization; high demand of water during the peak tourist season; insufficient aquifer recharge and sea level rise (Antonellini et al. 2008).
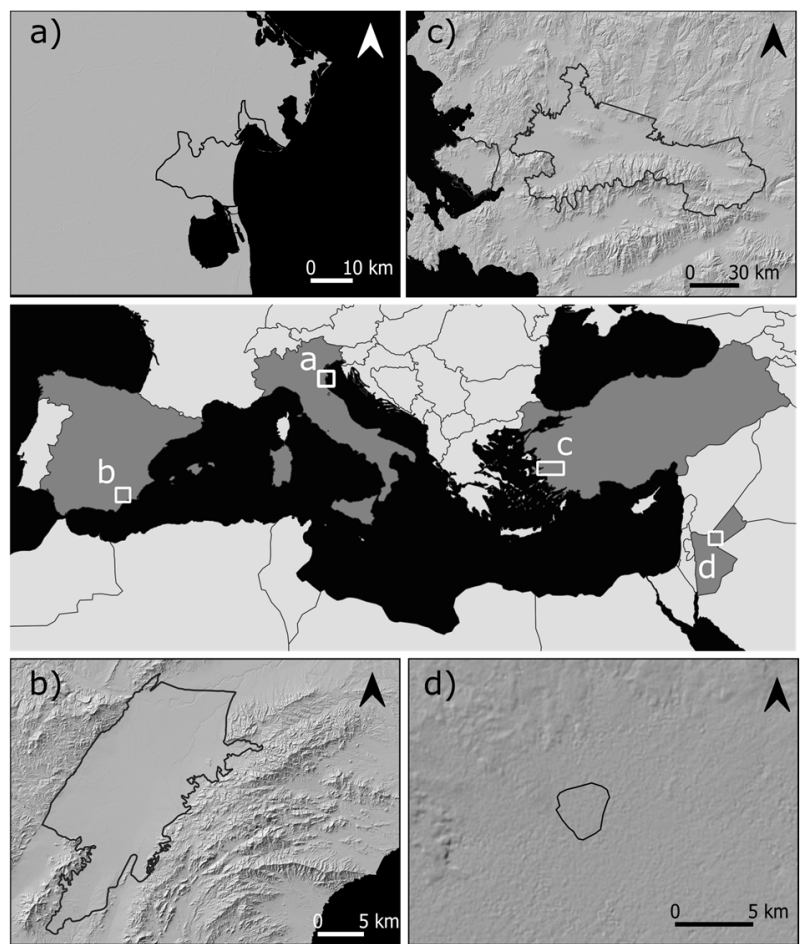

Figure 1: Location of the four pilot sites: a) Comacchio coastal aquifer; b) Alto Guadalentín basin; c) Gediz River Basin; d) Azraq Wetland Reserve.

The Alto Guadalentín Basin is an intramontane tectonic depression located in Murcia Region, southeast Spain, in the detrital and sedimentary filling of a large basin developed by tectonic shifts. The average thickness of the filling layers reaches more than $300 \mathrm{~m}$. However, as a consequence of the horst and graben structure of the bedrock this thickness increases locally up to $900 \mathrm{~m}$ (Cerón, 1995). The layers present from the top are PlioQuaternary materials subdivided in soft soils (aquitard) and coarse fraction (aquifer) (Béjar-Pizarro et al. 2016; Bonì et al. 2015), Miocene materials that act as low permeability or impervious limit and lastly the Palaeozoic metamorphic substrate. In the 60's hundreds of wells were drilled to improve agriculture's productivity, but led to the declaration of overexploitation in 1987 (Cerón and Pulido-Bosch 1996). The piezometric levels have been continuously descending over the last 60 years, although in the last years they have been partially stabilized. Subsidence rates are the highest ones measured in Europe related to groundwater withdrawal (> $10 \mathrm{~cm} / \mathrm{yr})$ 
(Ezquerro et al. 2020; Fernández et al. 2018; González and Fernández 2011; Rigo et al. 2013).

The Gediz River Basin, located in the Aegean region of Turkey, is one of the largest out of 25 major watersheds and most water-stressed river basins in the country. The basement is formed by metamorphic rocks of the Menderes Massive (Bulut et al. 2020; DSI 2014) covered by Quaternary basalts and alluvium units. There are 76 groundwater bodies or aquifers consisting of different lithological units (TUBITAK-MAM 2018). The ones formed by sedimentary-alluvial deposits constitute a significant share of the total groundwater potential in the basin (DSI 2014) and are referred to as the alluvial aquifer or the Gediz Plain Aquifer. The agriculture sector is the largest groundwater user since the basin is agriculture-dominant; however, significant competition for water exists among various stakeholders and other sectors. The main socioeconomical activities are agriculture, animal husbandry, food industry, textile industry and mining. There are more than 40,000 registered wells mostly in alluvial aquifers on the basin. In addition, there are thousands of unregistered wells for which the actual total groundwater withdrawal rate is unknown. Land subsidence linked to overexploitation of groundwater is observed in some parts of the basin, however it does not cause any major problems yet. The aquifer is also affected by groundwater pollution and deterioration due to agriculture, interaction with polluted river water and geothermal water influence.

The Azraq Wetland Reserve is an Oasis of international importance for its biodiversity and constitutes one of the most peculiar ecosystems in the world. It is located in the heart of an extensive trans-boundary groundwater basin in the northeaster part of the Desert of Jordan. The basin seems to have developed during the Paleozoic (Abed 2018) and represents a thick stratigraphic section (ElNaqa 2010). Groundwater systems in the basin can be divided into three main hydraulic complexes ranging from recent deposits to deep sandstone aquifer complexes. During the last two decades, overexploitation of the groundwater in the basin for human consumption and irrigation, has caused lowering of the basin water table and, consequently, the salinity has increased. The latter has exposed the Reserve, which has an important social and economic role for the local community, to severe pressure, and ecosystems are in far stage of degradation.

\section{Methodology}

The preliminary assessment of ground deformation at the four aquifers has been done using S-1 SAR images processed with two different algorithms of the GEP. These preliminary results are the first step towards integrating A-DInSAR into aquifer deformation models within the frame of the RESERVOIR project (Fig. 2). With these satellite observations we can identify potential deformation areas before carrying out a more work demanding and conclusive A-DInSAR analysis with supervised procedures, that will be used to characterize and calibrate groundwater flow and deformational numerical models. This will provide insights and knowledge about the impacts of overexploiting groundwater resources for irrigation, industry or tourism demands, and how is related to land subsidence and related impacts or risks. The new products and services will be handled to the stakeholders.

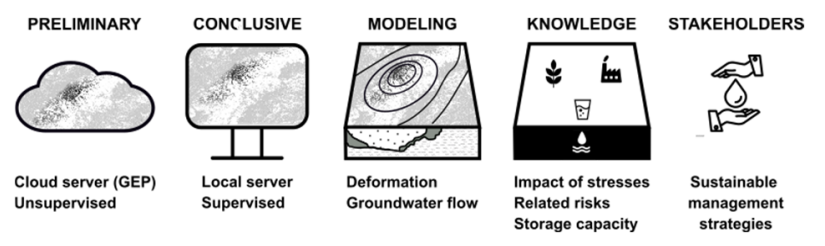

Figure 2: Workflow to integrate A-DInSAR into aquifer deformation models within the frame of the RESERVOIR project.

Data processing was carried out with the P-SBAS and FASTVEL services integrated in GEP. The input data are S-1 Single Look Complex (SLC) SAR acquisitions in Interferometric Wide (IW) swath mode. The thematic apps on GEP require a mandatory registration step on the ESA web portal (gpod.eo.esa.int/), by creating an ESA Earth Observation Single Sign-On (EO-SSO). GEP provides a list of processing tutorials in Terradue (2020) where the configuration and outputs of each processor is detailed. A brief description of each processor is outlined below.

\subsection{P-SBAS}

The Small BAseline Subset (SBAS) approach (Berardino et al. 2002) is a seminal work that proposes a complete A-DInSAR procedure using small baselines to limit the spatial decorrelation, multilooked data to reduce phase noise, and a coherence-based selection criterion. PSBAS is the parallel computing solution developed by CNR-IREA for the SBAS processing chain to deal with the current scenario characterized by huge SAR archives (Casu et al. 2014). The P-SBAS InSAR S-1 Terrain Observation with Progressive Scans (TOPS) service implemented in GEP supports S-1 TOPSAR IW SLC data (Galve et al. 2017). Just a few parameters of the processing can be selected, such as the coherence threshold which can be set in the 0.7-0.9 range (the default is 0.85), the area of interest (AOI), and the reference point coordinates. However, as addressed by Galve et al. (2017), if the point that is selected by the user is not coherent, the processing tool selects another reference point without any possibility of interaction. Currently, a mandatory step must be performed before launching the P-SBAS job, which is ordering the S-1 acquisitions older than a few months through the "DIAS product order" utility, as they were put offline at the end of 2020 due to change of policy at the main data providers. In practice, the DIAS ONDA provider recommends that users consider running the utility at least two times for a sanity check. The main outputs of the processing are pixel location (geographic coordinates), displacement time series (TS) in LOS [cm], mean LOS velocity [cm/year], temporal coherence, and LOS unit vectors along the north, east and vertical directions. The sign criteria are negative values indicating movement away from the satellite and positive towards the satellite. The multilook applied is $5 \times 20$ (azimuth $x$ range) which generates pixels in the size of about $90 \times 90 \mathrm{~m}$. In practice, it is recommended to select an AOI that spans at least four S1 bursts (Fig. 3), which approximately corresponds to 80 $\mathrm{km}$ along azimuth. Automatically, the algorithm will process the entire swath of the image $(250 \mathrm{~km}$ in range direction) and the azimuth specified by the user. 


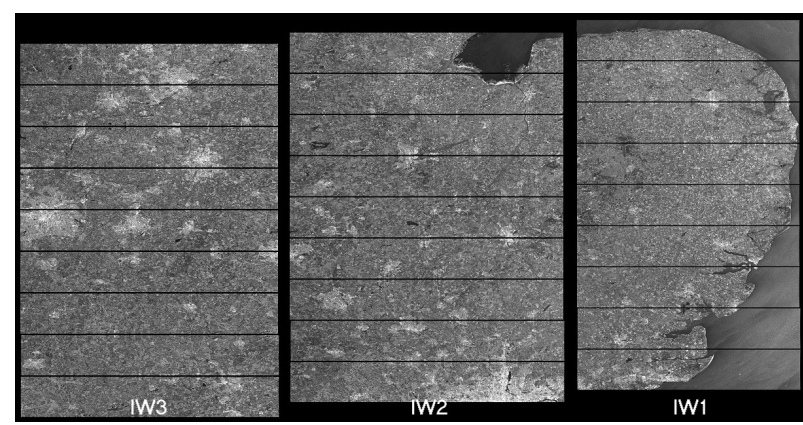

Figure 3: S-1 SLC IW mode captures three sub-swaths (range) and nine Bursts (azimuth) using Terrain Observation with

Progressive Scans SAR (TOPSAR). Image from ESA (2021).

\subsection{FASTVEL}

FASTVEL algorithm was developed by TRE-Altamira for generating differential interferograms or PSI-based mean displacement velocity maps from a set of $\mathrm{S}-1$ or ASAR images. A minimum number of 25 images are required and no pre-ordering step is needed. The parameters to be considered are: AOI, reference point coordinates, maximum temporal baseline (default value 365 days), maximum perpendicular baseline (default $400 \mathrm{~m}$ ), maximum doppler difference (default $1000 \mathrm{~Hz}$ ), maximum doppler centroid (default $2000 \mathrm{~Hz}$ ), interferometric coherence threshold, and Atmospheric Phase Screen (APS) correlation distance (default $3000 \mathrm{~m}$ ). In all the FASTVEL processes presented in this work the values have been set to the default, with the exception of the interferometric coherence threshold which has been set in the range of 0.50 to 0.85 . The main outputs of the processing are pixel location (geographic coordinates), mean LOS velocity [cm/year], height error [m], temporal coherence, and LOS unit vectors. The sign criteria are negative values indicating movement away from the satellite and positive towards the satellite. The product's pixel size is approximately $40 \times 40 \mathrm{~m}$. In practice, it is recommended to select an $\mathrm{AOI}$ of about $30 \times 30 \mathrm{~km}$ in areas where high pixel density is expected and up to $70 \mathrm{x}$ $70 \mathrm{~km}$ in areas where low pixel density is expected. The algorithm will only process the AOI specified by the user.

\section{Results}

In this section the results of the preliminary assessment of ground deformation of the four pilot sites obtained with the P-SBAS and the FASTVEL A-DInSAR services in GEP are presented. The periods studied are similar, ranging from end 2016 to beginning 2021. As it was mentioned, P-SBAS also provide displacement time series in LOS, but only the mean LOS velocity will be analysed. Note that the extent processed with P-SBAS is much larger than for FASTVEL. The coherence can be theoretically defined on a pixel basis as the correlation coefficient that varies in the range of 0 to 1 . It significantly influences the accuracy of phase in the interferogram; the higher coherence (more restrictive), the better the quality. The threshold limits the selection of pixels above the specified coherence value.

\subsection{Coastal aquifer of Comacchio}

Four different preliminary mean LOS velocity maps are presented for Comacchio pilot site. The P-SBAS algorithm was performed in ascending (ASC) (Fig. 4 upper left) and descending (DES) (Fig. 4 upper right) orbits using $100 \mathrm{~S}-1$ SAR images in both cases and covering the period January 2016 to May 2019 and September 2017 to January 2021 respectively. The FASTVEL algorithm was also performed in ASC (Fig. 4 lower left) and DES (Fig. 4 lower right) orbits using 125 and 37 S-1 SAR images respectively, covering the period January 2016 to May 2019. The threshold coherences for each processing is shown in Table 1. The reference point was placed in a stable area according to previous Global Positioning System (GPS) 2011-2016 subsidence studies (Bonsignore et al. 2018).

Table 1: Main characteristics of the A-DInSAR processing performed in GEP. Type of service or thematic application, orbit direction, number of images $(\mathrm{N})$, track and coherence threshold

(Coh). ASC and DES stand for ascending and descending orbits of the satellite, respectively.

\begin{tabular}{c|c|c|c|c|c} 
Site & Service & Orbit & $N$ & Track & Coh. \\
\hline Comacchio & P-SBAS & ASC & 100 & 117 & 0.85 \\
& & DES & 100 & 95 & 0.70 \\
Alto & FASTVEL & ASC & 125 & 117 & 0.50 \\
Guadalentín & & DES & 37 & 95 & 0.55 \\
& & ASC & 100 & 103 & 0.85 \\
Gediz & FASTVEL & DES & 79 & 8 & 0.50 \\
Gediz West & P-SBAS & DES & 138 & 138 & 0.85 \\
& & & 123 & 36 & \\
Gediz East & P-SBAS & ASC & 111 & 131 & 0.85 \\
& FASTVEL & ASC & 60 & 131 & 0.50 \\
Azraq Wetland & P-SBAS & ASC & 98 & 131 & 0.85 \\
& FASTVEL & ASC & 73 & 131 & 0.50 \\
& P-SBAS & DES & 124 & 21 & 0.85 \\
& FASTVEL & ASC & 104 & 14 & 0.75 \\
& & & 104 & & 0.85
\end{tabular}

All analyses include completely the Goro Gorino and Po di Volano areas of interest, which are delimited in black in Figure 4. For all the analysis the stable velocities represented in the maps have been set in the same range of -0.5 to $0.5 \mathrm{~cm} /$ year (white) as it is the mean value of standard deviation and for the sake of comparison. Both P-SBAS results (ASC/DES) are similar with mean LOS velocities ranging from -3.5 to $1.5 \mathrm{~cm} /$ year in the common area with the FASTVEL processing extent (approximately $75 \times 75 \mathrm{~km}$ ). FASTVEL results, obtained with less restrictive coherence values for the reasons explained in Section 5, are noisier, especially the ASC orbit where a ramp in velocity is observed from the West (positive values) to the East (negative) of the scene (Fig. 4). Also, there are randomly distributed pixels showing not explained high uplifts or movement towards the satellite. Velocities in LOS range from -14.3 to $6.2 \mathrm{~cm} /$ year in DES orbit and up to -20.5 to 30.8 in ASC. These artefacts are probably caused by the temporal decorrelation, or coherence loss, that occurs in spring and summer, due to 
the crops growing cycle. A clear deformation pattern associated to land subsidence could not be retrieved in the Comacchio aquifer area. This is a historically affected subsidence area, which present day displacement rates are low $(\mathrm{mm} / \mathrm{yr})$ and locally accelerated by the construction of new buildings and structures (Vitagliano et al. 2020). Further local scale analysis will be performed to investigate the multi-component low subsidence rates that have implications for the flooding of the coastal area and the saltwater contamination of the soils and groundwater resources.
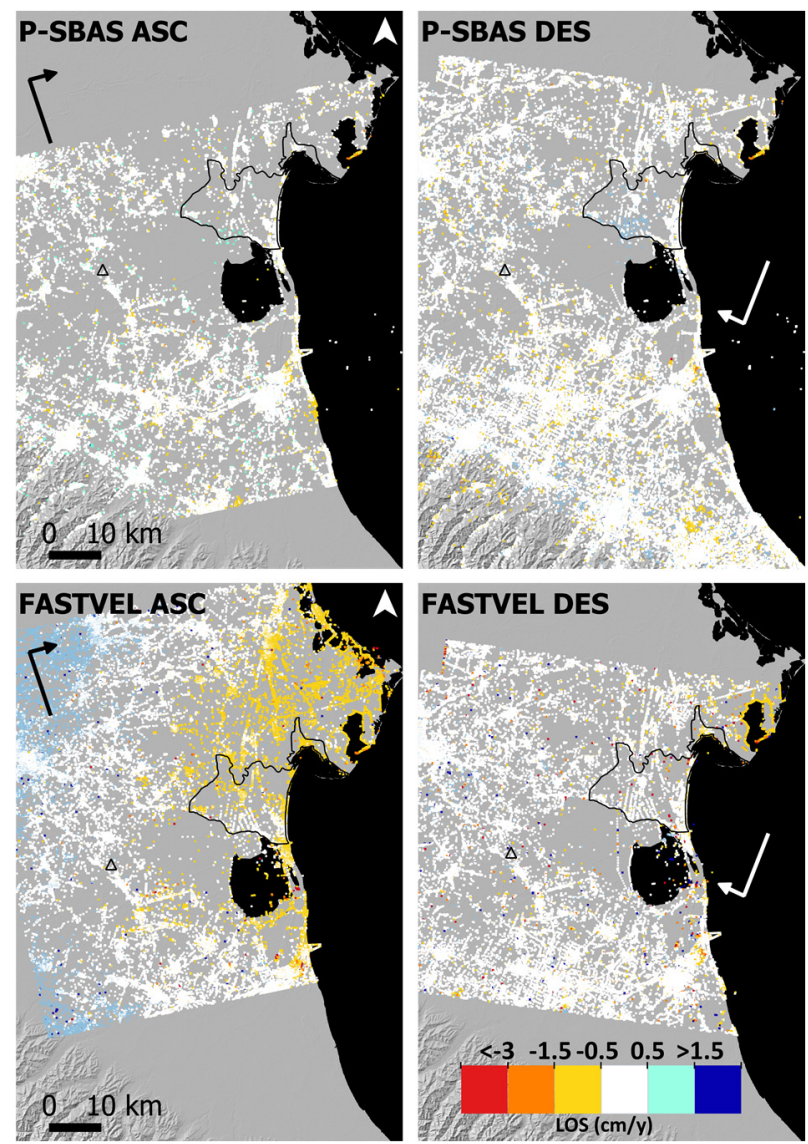

Figure 4: P-SBAS (upper) and FASTVEL (lower) mean LOS velocity $(\mathrm{cm} / \mathrm{y})$ maps. Reference point selected by the user is marked with a black triangle.

\subsection{Alto Guadalentín basin}

As for the previous pilot site, three different preliminary mean LOS velocity maps are presented for Alto Guadalentín. The P-SBAS algorithm was performed in ASC (Fig. 5 upper left) and DES (Fig. 5 upper right) orbits using 100 and 102 S-1 SAR images respectively, covering the period January 2017 to January 2021. The FASTVEL algorithm was only performed in DES mode (Fig. 5 lower) using 79 S-1 SAR images and covering the period June 2017 to January 2021. The threshold coherences for each process are shown in Table 1. The reference point was placed in the mountain range of the West.

All the datasets cover the whole extent of the aquifer boundary. The stable threshold has been set in the range of -0.5 to $0.5 \mathrm{~cm} /$ year based on the standard deviation values, although previous InSAR studies revealed that radar noise over this area is usually high and stability thresholds around $\pm 1 \mathrm{~cm} /$ year were used (Bonì et al. 2015). The deformation pattern is very consistent among the datasets and the pixel density is relatively high. The maximum deformation area is located in the northern section of the basin, with rates in LOS ranging from -4.5 up to $-6.9 \mathrm{~cm} /$ year. These results agree with previous studies (Béjar-Pizarro et al. 2016; Bonì et al. 2015; Ezquerro et al. 2017; Ezquerro et al. 2020). Again, FASTVEL results obtained with coherence values of 0.50 against the 0.85 of P-SBAS, seem noisier. The deformation pattern coincides spatially with other monitoring data, such as CSK, ALOS-PALSAR and ENVISAT from previous studies (Béjar-Pizarro et al. 2016; Bonì et al. 2015; Ezquerro et al. 2017; Ezquerro et al. 2020; González and Fernández 2011).
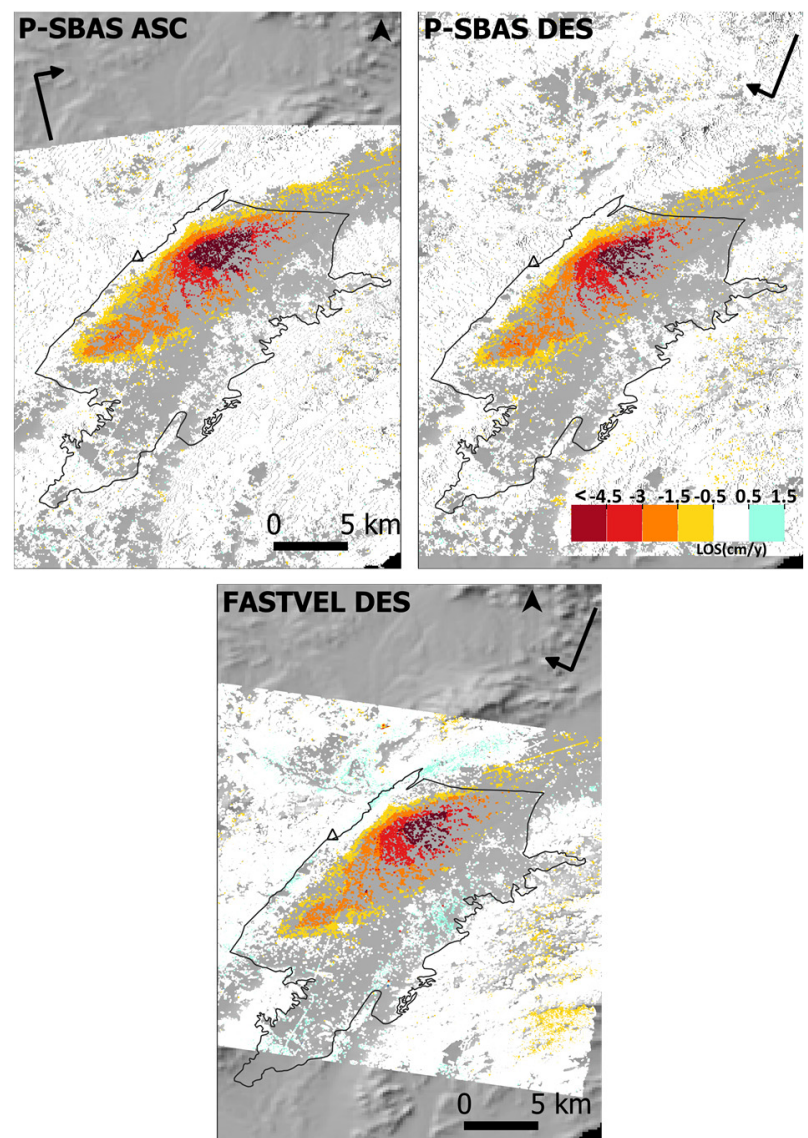

Figure 5: P-SBAS (upper) and FASTVEL (lower) mean LOS velocity $(\mathrm{cm} / \mathrm{y})$ maps. Reference point selected by the user is marked with a black triangle.

Regarding the velocity range, they also agree, although it has to be considered that the studied periods are different from this work to previous ones.

\subsection{Gediz River Basin}

A complete picture of the deformation at the Gediz basin was obtained by processing separately two DES tracks datasets with the P-SBAS thematic application and plotting the results together (Fig. 6). The period for both of them is from June 2016 to July 2020. Movement away from the satellite was clearly detected in the western section, more precisely towards the southern coast which is an urbanized area that belongs to Izmir city. In the eastern section of the basin movement is detected in various patches, being the most relevant the one in the 
eastern part, which is an agricultural area surrounding the towns of Alaşehir and Sarıgöl.

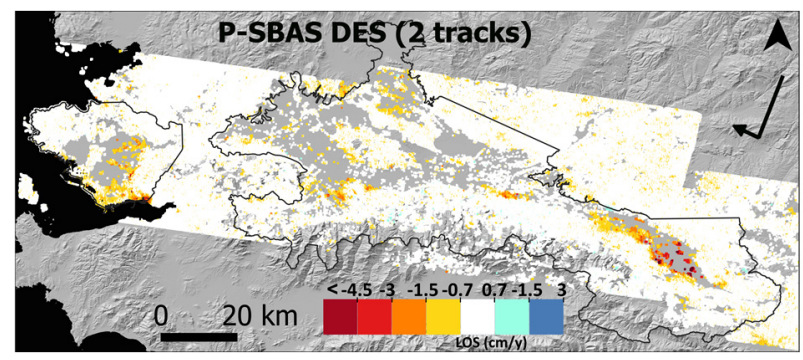

Figure 6: Mean LOS velocity map of the entire Gediz Basin of two distinct P-SBAS processes of two different DES tracks.

Further analysis has been performed in these two areas with S-1 datasets in ASC orbit (Fig. 7). The period studied for the west area is July 2017 to February 2021 (upper part of Fig. 7). Both algorithms detect movement with peak LOS rates greater than $-4.5 \mathrm{~cm} /$ year at the central lowlands (that has low pixel density), at the southwestern area along the coast that is covered by salt evaporation ponds (coherent targets are along the paths) and at the south eastern limit of the AOI over the metropolitan city area (high pixel density). However, there are discrepancies between P-SBAS and FASTVEL. In the metropolitan area, the FASTVEL results detect a small patch with movement towards the satellite, meanwhile $P$ SBAS detect it as down lift. Also, at the upper right corner of the FASTVEL scene, there is a section showing low movement away from the satellite that neither P-SBAS ASC or DES actually detect (Fig. 7 upper).

The periods studied for the East area are December 2017 to February 2021 (P-SBAS) and June 2017 to February 2021 (FASTVEL). The pixel density is relatively low in the basin due to coherence loss of the agricultural land coverage. High deformation rates away from the satellite are detected along the centre of the basin. Mountain ranges at the sides appear stable (not moving) in both DES and ASC P-SBAS results, however FASTVEL detects slight up lift in the SW of the scene.

\subsection{Azraq Wetland Reserve}

Five different preliminary mean LOS velocity maps are presented for Azraq Wetland Reserve. The reference point for all of them coincide with a GNSS station that does not detect any movement. The P-SBAS algorithm was performed in DES orbit (Fig. 8) covering the period October 2016 to December 2020. Most of the landcover is bare land which exhibits high coherence among the SAR scenes and, therefore, the pixel coverage is also significant, except for the grey patch (no data) that correspond to the wetland. Movement away from the satellite is detected surrounding the Reserve area, with peak LOS rates of $-4.5 \mathrm{~cm} /$ year. Small areas of movement towards the satellite are also detected.

The FASTVEL algorithm was run with ASC (January 2017to December 2020) and DES (October 2016 to February 2021) datasets with different coherence values, which are much more restrictive that the ones used in the other areas (Table 1 and Fig. 9). The reason is because the processes run in GEP failed with lower coherence values, that could be due to the big number of selected pixels in the highly coherent terrain surface. The pixel coverage is substantially reduced, however the deformation area at the north of the Reserve is well detected in the four maps with mean velocity values and a spatial coverage similar to the P-SBAS results. The FASTVEL ASC result, which was done with the lowest coherence, exhibits a ramp in the South- North direction.
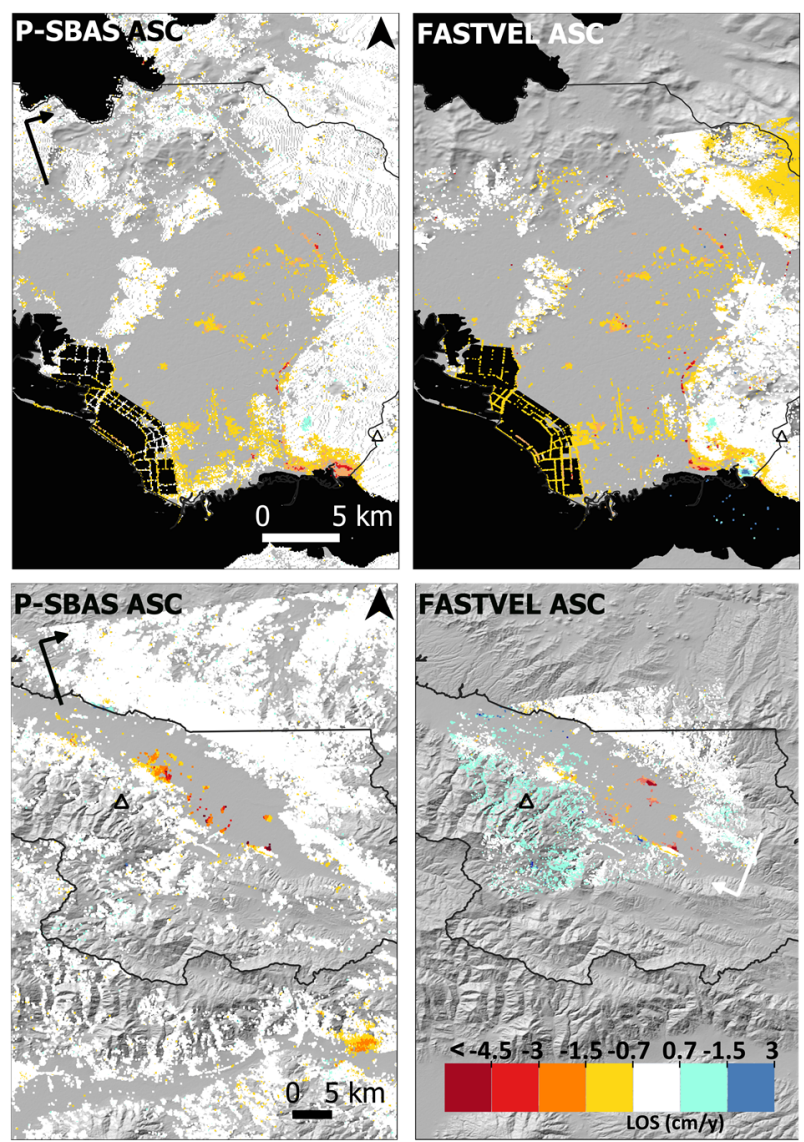

Figure 7: P-SBAS and FASTVEL mean LOS velocity $(\mathrm{cm} / \mathrm{y})$ maps of the West part of the Gediz basin (upper) and the Eastern part (lower). Reference point selected by the user is marked with a black triangle.

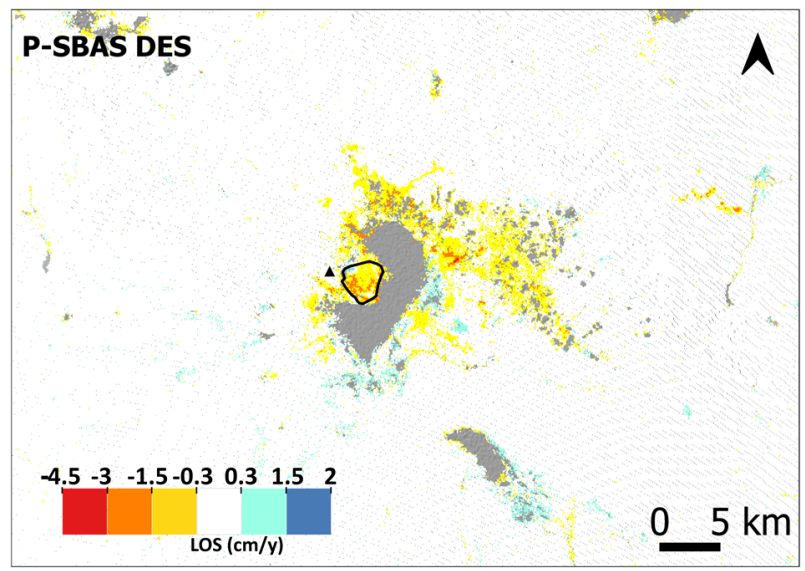

Figure 8: Mean LOS velocity map obtained with P-SBAS of the Azraq Wetland Reserve.

\section{Discussion}

In this section we will discuss the different performance of the two A-DInSAR algorithms used in this work and their versatility to generate preliminary land subsidence maps. 
The most relevant difference is that P-SBAS provides LOS rates and LOS displacement time series, meanwhile FASTVEL only provides the former. However, GEP should be taken as an exploratory tool to obtain the mean LOS velocities, that are taken as preliminary results for the RESERVOIR project proposes. Although displacement time series (TS) obtained with P-SBAS have been used to interpret surface terrain deformation in previously studied areas where the geologic phenomena is well known (Cigna and Tapete 2021), we are cautious on their reliability for making precise analysis. The reason is that the processing chain runs without user supervision, which adds more uncertainty to the intrinsic limitations of the technique. For example, the criteria to discard or not certain interferograms is unknown and cannot be controlled. We have experienced that in general the FASTVEL algorithm discards more interferograms, as the metadata of the process reveals that the SAR images used for the LOS velocity calculations is less than the selected. FASTVEL gives to the user the option to change more parameters than P-SBAS (Section 3.2), however we have not performed a sensitivity test and the default values were used for all the analysis.

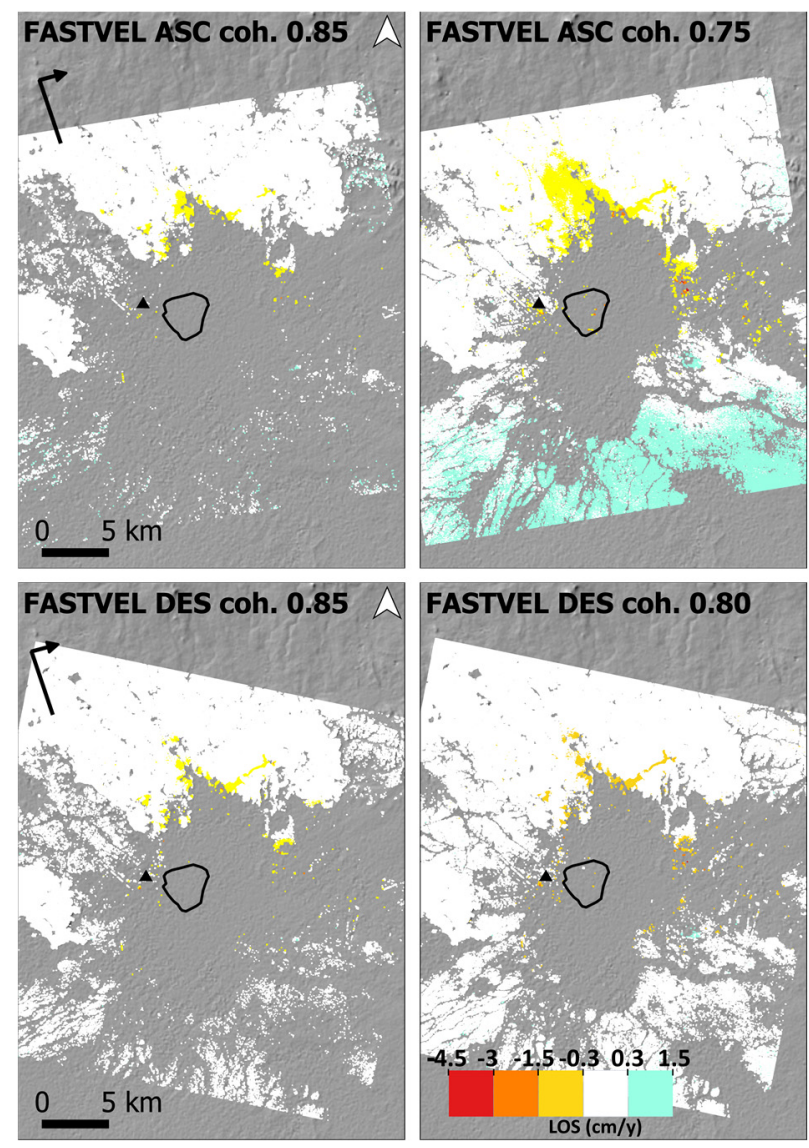

Figure 9: FASTVEL mean LOS velocity $(\mathrm{cm} / \mathrm{y})$ maps of the Azraq Wetland Reserve with ASC orbit dataset (upper) and DES orbit dataset (lower). Reference point selected by the user is marked with a black triangle.

Other important distinctions are the extent that can be processed, as already discussed in Section 3, and the processing time. For FASTVEL is around 24 hours (for 100 images in $30 \times 30 \mathrm{~km}$ ) and for P-SBAS is up to 48 hours (for 100 images in $80 \times 250 \mathrm{~km}$ ) plus the preordering step in DIAS (20 S-1 SAR images per hour).
Both algorithms use the same method to create the stack of interferograms and also the same criterion to select the punctual targets in the interferograms in which the deformation will be computed. P-SBAS and FASTVEL use a small baseline configuration, where a denser interferogram network is created linking multiple SAR images (Multi-master). Is a coherence-based method that use distributed scatters (DS), or in other words, areas whose scatter properties are not altered with time. The coherence estimation requires a spatial average within a two-dimension window, usually named as multilook. The multilook processing allows to reduce noise at the expenses of a resolution loss (Mestre-Quereda et al. 2018). P-SBAS uses a multilook of $5 \times 20$ (azimuth $x$ range) which generates pixels or DS size of about $90 \times 90$ $\mathrm{m}$. On the other hand, FASTVEL DS size is $40 \times 40 \mathrm{~m}$, so the multilook applied, although not specified in the documentation of the Thematic Application, must be of around $2 \times 5$. The bigger pixel size of P-SBAS improves the spatial coverage, especially in non-urban areas (Fig. 10 left and Fig. 11 left). However, in very coherent locations, such as urban fabric, roads or even pathways, FASTVEL will provide more DS, because it has a higher resolution or smaller pixel size (Fig. 10 right and Fig. 11 right). The low resolution or bigger pixel size of the $\mathrm{P}$ SBAS DS also allows the use of more restrictive coherence thresholds without compromising data coverage, as it has been experienced in all the pilot sites. Contrarily, to have a good spatial coverage with FASTVEL it is required to use a lower coherence threshold (around 0.50 to 0.55 ), which introduces noise, ramps and false uplifts in the results.
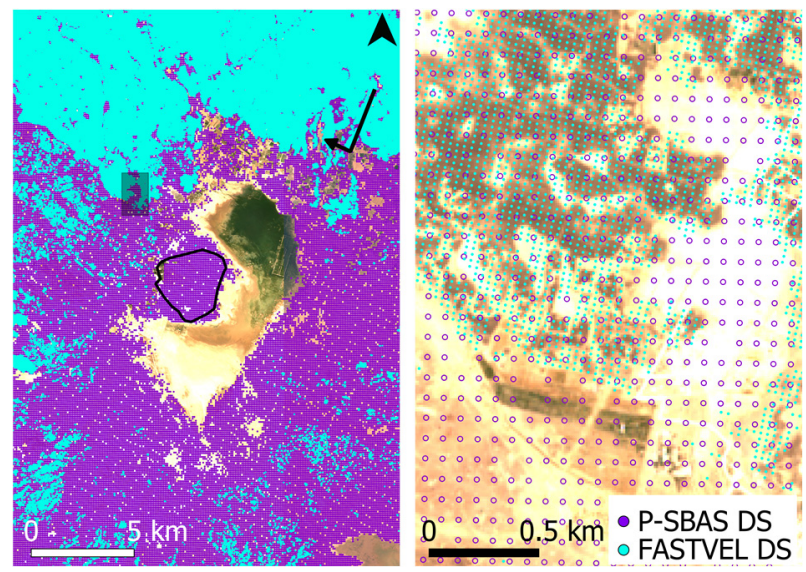

Figure 10: Comparison between DS spatial coverage (left) and DS density (zoomed rectangle at the right) from very similar

SAR datasets processed with the two different algorithms in the Azraq Wetland Reserve. Land cover is characterized by bare land with no vegetation. DS are represented as points that would be at the centre of each pixel. Both SAR datasets have a DES orbit, same track and the same threshold coherence (0.85). Time period for P-SBAS is October 2016 to December 2020 (124 S1 images) and for FASTVEL October 2016 to February 2021 (125 S1 images).

\section{Conclusions}

We have obtained successful processes in GEP with both P-SBAS and FASTVEL algorithms in all the four pilot sites.

We could delimit clear moving areas that can be related to land subsidence in Alto Guadalentín, Gediz River Basin and Azraq Wetland Reserve pilot sites. The dense 
agricultural coverage and the crops growing cycle in Comacchio pilot site, compromises the retrieval of reliable information. The results are consistent between ASC and DES modes and also between the algorithms, despite certain differences that have been addressed in Section 4 and discussed in Section 5.
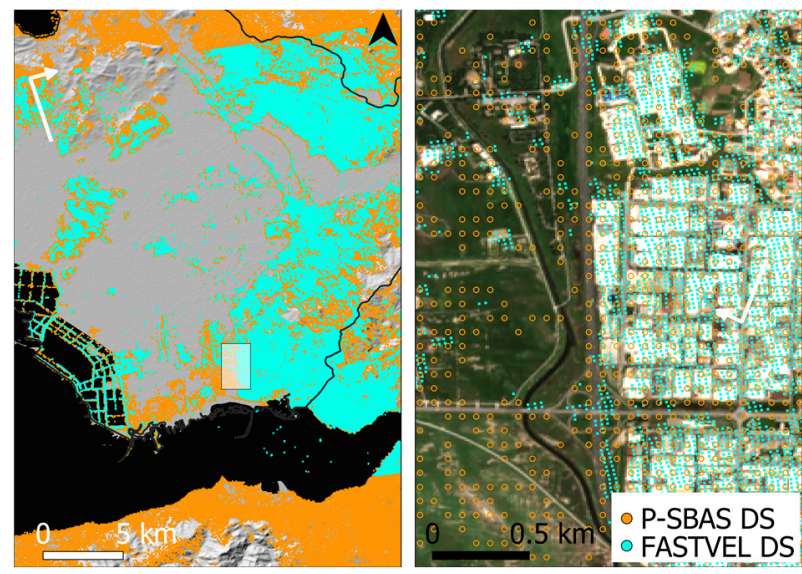

Figure 11: Comparison between DS spatial coverage (left) and DS density (zoomed rectangle at the right) obtained with each algorithm in the western Gediz Basin, that has urban and agricultural land cover. Both datasets are ASC and from the same track. The threshold coherence is 0.85 for P-SBAS and 0.50 for FASTVEL. The time period is June 2017 to February 2021 for both datasets, using 111 S-1 images for P-SBAS and 60 for FASTVEL.

We have experienced that the lower coherence threshold (needed to have a good data coverage) of the FASTVEL processing's, introduce more noise and sometimes false uplifts.
For studying large areas P-SBAS is more suitable. We could retrieve a useful deformation picture of the entire Guediz Basin in Turkey. Other advantages are that those unknown hotspots outside the AOI can be detected, the spatial coverage is better (although it has a lower a resolution) and displacement TS are also delivered.

The GEP tools used in this study have some limitations that need to be considered: the main drawback is that they are unsupervised processes, meaning they are a black box which compromises the reliability of the results to perform detailed interpretations. We neither assure the ability to reproduce the exact processing in the platform. Also, the server is sometimes unstable (disabling to run the jobs).

Nonetheless, we find that GEP tools are very useful for preliminary land subsidence analysis. All the technical resources are external, SAR images and algorithms are located together which simplifies the process, the interfaces are user friendly, and the processes are very fast (especially FASTVEL). As addressed by Cigna and Tapete (2021), the platform allows SAR Big Data processing by providing accessibility to a cloud/grid infrastructure and chains to process such huge datasets.

\section{Acknowledgements}

This work was supported by RESERVOIR project, which is part of the PRIMA Programme supported under Horizon 2020 the European Union's Framework Programme for Research and Innovation. Grant Agreement number: [1924] [RESERVOIR] [Call 2019 Section 1 Water RIA].

Copernicus Sentinel-1 IW SAR data were provided and processed in ESA's Geohazards Exploitation Platform (GEP), in the framework of the GEP Early Adopters Programme.

\section{References}

ABED, A. M., 2018. Geological evolution of the Azraq basin, eastern Jordan: An overview. Jordan Journal of Natural History, 5, pp. 6-52.

ANTONELLINI, M., MOLLEMA, P., GIAMBASTIANI, B., BISHOP, K., CARUSO, L., MINCHIO, A., PELLEGRINI, L., SABIA, M., ULAZZI, E., and GABBIANELLI, G., 2008. Salt water intrusion in the coastal aquifer of the southern Po Plain, Italy. Hydrogeology journal, 16(8), 1541.

BÉJAR-PIZARRO, M., GUARDIOLA-ALBERT, C., GARCÍA-CÁRDENAS, R. P., HERRERA, G., BARRA, A., LÓPEZ MOLINA, A., TESSITORE, S., STALLER, A., ORTEGA-BECERRIL, J. A., and GARCÍA-GARCÍA, R. P., 2016. Interpolation of GPS and geological data using InSAR deformation maps: Method and application to land subsidence in the alto guadalentín aquifer (SE Spain). Remote Sensing, 8(11), 965.

BERARDINO, P., FORNARO, G., LANARI, R., and SANSOSTI, E., 2002. A new algorithm for surface deformation monitoring based on small baseline differential SAR interferograms. Geoscience and Remote Sensing, IEEE Transactions on, 40(11), pp. 2375-2383.

BONì, R., HERRERA, G., MEISINA, C., NOTTI, D., BÉJAR-PIZARRO, M., ZUCCA, F., GONZÁLEZ, P. J., PALANO, M., TOMÁS, R., and FERNÁNDEZ, J., 2015. Twenty-year advanced DInSAR analysis of severe land subsidence: The Alto Guadalentín Basin (Spain) case study. Engineering Geology, 198, pp. 40-52.

BONSIGNORE, F., CARATI, M., COSTANTINO, R., CRISTOFORI, D., ZACCANTI, G., BITELLI, G., VITTUARI, L., FRANCI, F., LAMBERTINI, A., MARTELLI, L., and SEVERI, P., 2018. Rilievo della subsidenza nella pianura emilianoromagnola - Seconda fase. ARPAE Direzione Tecnica, Università di Bologna DiCAM, Regione Emilia-Romagna Servizio Geologico, Sismico e dei Suoli.

BULUT, O. F., DURU, B., ÇAKMAK, Ö., GÜNHAN, Ö., DILEK, F. B., and YETIS, U., 2020. Determination of groundwater threshold values: A methodological approach. Journal of Cleaner Production, 253, pp. 120001.

CARBOGNIN, L., and TOSI, L., 1995. Situazione altimetrica attuale del comprensorio veneziano ei suoi riflessi sull'ambiente lagunare. Primo Convegno Del Gruppo Nazionale Di Geologia Applicata. 
CARMINATI, E., DOGLIONI, C., and SCROCCA, D., 2005. Magnitude and causes of long-term subsidence of the Po Plain and Venetian region. Books, 40, pp. 10011-14211.

CASTELlARIN, A., EVA, C., GIGLIA, G., VAI, G., RABBI, E., PINI, G., and CRESTANA, G., 1985. Analisi strutturale del fronte appenninico Padano. Giornale di Geologia, 47(1-2), 3rd series, pp. 47-75.

CASU, F., ELEFANTE, S., IMPERATORE, P., ZINNO, I., MANUNTA, M., DE LUCA, C., and LANARI, R., 2014. SBASDInSAR parallel processing for deformation time-series computation. IEEE Journal of Selected Topics in Applied Earth Observations and Remote Sensing, 7(8), pp. 3285-3296.

CERÓN, J. C., 1995. Estudio hidrogeoquímico del acuífero del Alto Guadalentín (Murcia). PhD: University of Granada, Granada, Spain, p. 265.

CERÓN, J., and PULIDO-BOSCH, A., 1996. Groundwater problems resulting from CO 2 pollution and overexploitation in Alto Guadalentín aquifer (Murcia, Spain). Environmental Geology, 28(4), pp. 223-228.

CIGNA, F., and TAPETE, D., 2021. Sentinel-1 BigData Processing with P-SBAS InSAR in the Geohazards Exploitation Platform: An Experiment on Coastal Land Subsidence and Landslides in Italy. Remote Sensing, 13(5), pp. 885.

DE LUCA, C., CUCCU, R., ELEFANTE, S., ZINNO, I., MANUNTA, M., CASOLA, V., RIVOLTA, G., LANARI, R., and CASU, F., 2015. An on-demand web tool for the unsupervised retrieval of earth's surface deformation from SAR data: The PSBAS service within the ESA G-POD environment. Remote Sensing, 7(11), pp. 15630-15650.

DSI, 2014. Hydrogeological Study of the Gediz Watershed. State Hydraulic Works of Turkey: Ankara, Turkey (in Turkish).

EL-NAQA, A., 2010. Final Report Study of salt water intrusion in the Upper Aquifer in Azraq Basin. IUCN-International Union for Conservation of Nature.

ESA 2021. User Guides - Sentinel-1 SAR - Interferometric Wide Swath - Sentinel Online - Sentinel (esa.int). https://sentinel.esa.int/web/sentinel/user-guides/sentinel-1-sar/acquisition-modes/interferometric-wide-swath [6/22, 2021].

EZQUERRO, P., GUARDIOLA-ALBERT, C., HERRERA, G., FERNÁNDEZ-MERODO, J. A., BÉJAR-PIZARRO, M., and BONì, R., 2017. Groundwater and subsidence modeling combining geological and multi-satellite SAR data over the alto guadalentín aquifer (SE Spain). Geofluids, 2017.

EZQUERRO, P., TOMÁS, R., BÉJAR-PIZARRO, M., FERNÁNDEZ-MERODO, J., GUARDIOLA-ALBERT, C., STALLER, A., SÁNCHEZ-SOBRINO, J., and HERRERA, G., 2020. Improving multi-technique monitoring using Sentinel-1 and Cosmo-SkyMed data and upgrading groundwater model capabilities. Science of The Total Environment, 703, 134757.

FERNÁNDEZ, J., PRIETO, J. F., ESCAYO, J., CAMACHO, A. G., LUZÓN, F., TIAMPO, K. F., PALANO, M., ABAJO, T., PÉREZ, E., and VELASCO, J., 2018. Modeling the two-and three-dimensional displacement field in Lorca, Spain, subsidence and the global implications. Scientific reports, 8(1), pp. 1-14.

GALVE, J. P., PÉREZ-PEÑA, J. V., AZAÑÓN, J. M., ClOSSON, D., CALÓ, F., REYES-CARMONA, C., JABALOY, A., RUANO, P., MATEOS, R. M., and NOTTI, D., 2017. Evaluation of the SBAS InSAR service of the European space Agency's Geohazard Exploitation Platform (GEP). Remote Sensing, 9(12), 1291.

GALLOWAY, D. L., and HOFFMANN, J., 2007. The application of satellite differential SAR interferometry-derived ground displacements in hydrogeology: Hydrogeology Journal, 15(1), pp. 133-154.

GALlOWAY, D. L., HUDNUT, K. W., INGEBRITSEN, S., PHILLIPS, S. P., PELTZER, G., ROGEZ, F., and ROSEN, P., 1998. Detection of aquifer system compaction and land subsidence using interferometric synthetic aperture radar, Antelope Valley, Mojave Desert, California. Water Resources Research, 34(10), pp. 2573-2585.

GIAMBASTIANI, B. M., ANTONELLINI, M., ESSINK, G. H. O., and STUURMAN, R. J., 2007. Saltwater intrusion in the unconfined coastal aquifer of Ravenna (Italy): a numerical model. Journal of Hydrology, 340(1-2), pp. 91-104.

GONZÁLEZ, P. J., and FERNÁNDEZ, J., 2011. Drought-driven transient aquifer compaction imaged using multitemporal satellite radar interferometry. Geology, 39(6), pp. 551-554.

MESTRE-QUEREDA, A., LOPEZ-SANCHEZ, J. M., BALLESTER-BERMAN, J. D., GONZALEZ, P. J., HOOPER, A., and WRIGHT, T. J., 2018. Evaluation of the Multilook Size in Polarimetric Optimization of Differential SAR Interferograms. IEEE Geoscience and Remote Sensing Letters, 15(9), pp. 1407-1411.

PIERI, M., and GROPPI, G., 1981. Subsurface geological structure of the Po Plain, Italy, Verlag nicht ermittelbar.

RIGO, A., BÉJAR-PIZARRO, M., and MARTÍNEZ-DÍAZ, J., 2013. Monitoring of Guadalentín valley (southern Spain) through a fast SAR Interferometry method. Journal of Applied Geophysics, 91, pp. 39-48.

SIEBERT, S., BURKE, J., FAURES, J.-M., FRENKEN, K., HOOGEVEEN, J., DÖLL, P., and PORTMANN, F. T., 2010. Groundwater use for irrigation-a global inventory. Hydrology and earth system sciences, 14(10), pp. 1863-1880.

TEATINI, P., FERRONATO, M., GAMBOLATI, G., and GONELLA, M., 2006. Groundwater pumping and land subsidence in the Emilia-Romagna coastland, Italy: Modeling the past occurrence and the future trend. Water Resources Research, 42(1). 
TERRADUE 2020. Tutorials - Geohazards Thematic Exploitation Platform 3.0 documentation (terradue.com). https://docs.terradue.com/geohazards-tep/tutorials/index.html [6/22, 2021].

TOMÁS, R., ROMERO, R., MULAS, J., MARTURIÁ, J., MALLORQUI, J. J., LÓPEZ-SÁNCHEZ, J., HERRERA, G., GUTIÉRREZ, F., GONZÁLEZ, P., FERNÁNDEZ, J., DUQUE, S., CONCHA, A., COCKSLEY, G., CASTAÑEDA, C., CARRASCO, D., and BLANCO, P., 2014. Radar interferometry techniques for the study of ground subsidence phenomena: A review of practical issues through cases in Spain. Enviromental earth sciences, 71, pp. 163-181.

TUBITAK-MAM, 2018. Final Report of the Gediz River Basin Management Plan. The Scientific and Technological Research Council of Turkey, Marmara Research Center, Institute for Environment and Cleaner Production. Gebze/KOCAELI, Turkey, 617 pp. (in Turkish).

UNESCO, 2012. World's Groundwater Resources Are Suffering from Poor Governance. UNESCO Publishing: Paris, France.

VITAGLIANO, E., RICCARDI, U., PIEGARI, E., BOY, J. P., and DI MAIO, R., 2020. Multi-component and multi-source approach for studying land subsidence in deltas. Remote Sensing, 12(9), 1465. 